\title{
Treatment of Aged Skin with a pH 4 Skin Care Product Normalizes Increased Skin Surface pH and Improves Barrier Function: Results of a Pilot Study
}

\author{
Jürgen Blaak ${ }^{1}$, Rainer Wohlfart ${ }^{2}$, Nanna Y. Schürer ${ }^{1}$ \\ ${ }^{1}$ Department of Dermatology, Environmental Medicine and Health Theory, University of Osnabrück, Osnabrück, Germany; ${ }^{2}$ Research \\ and Development, Kneipp-Werke, Würzburg, Germany. \\ Email: jblaak@uni-osnabrueck.de
}

Received May 27 $7^{\text {th }}, 2011$; revised June $10^{\text {th }}, 2011$; accepted June $22^{\text {nd }}, 2011$.

\begin{abstract}
The physiological skin surface $p H$ is just below 5. With age the skin surface pH increases up to 6. An increased pH correlates with reduced barrier integrity/cohesion. The present pilot study assesses possible normalization of an increased skin surface $\mathrm{pH}$ of the elderly and improvement of barrier function via application of $\approx$ pH 4.0 skin care products. Baseline skin surface $p H$ was determined in elderly $(80+$ years old; $n=15)$ compared to middle aged adults $(31-$ 50 years old; $n=15)$. The effect of o/w emulsions at $p H$-values of 3.5, 4.0, 4.5 and 5.5 on the skin surface $p H$ was determined in both groups. Further, the effect of a 4-week treatment with a pH 4.0 skin care product on the skin surface $\mathrm{pH}$, skin hydration and barrier integrity was assessed. Thirteen elderly females were involved in this home-in-use test. Increased baseline skin surface pH of the elderly normalizes to the physiological pH of 4.5 - 5.0 over 7 hours after single application of o/w-emulsions with a given $\mathrm{pH}$ of 3.5 or 4.0. A 4-week treatment employing the pH 4.0 skin care product improves the epidermal barrier integrity of the elderly significantly $(p=0.005)$. Reduction of the increased baseline skin surface $\mathrm{pH}$ of the elderly is accompanied by improved epidermal barrier integrity. Skin care products for the elderly have to be adjusted in the pH range of 3.5 to 4.0 .
\end{abstract}

Keywords: Skin Aging, Skin Care, Skin Surface pH, Epidermal Barrier Function

\section{Introduction}

The physiological skin surface $\mathrm{pH}$ has been evaluated repeatedly. Even though the skin surface $\mathrm{pH}$ is still defined to be 5.4 - 5.9 [1], recent multicenter studies postulate a skin surface $\mathrm{pH}$ just below 5.0 appeared in 330 or 222 subjects [2-3]. The acid $\mathrm{pH}$ of the skin surface, known as the "acid mantle" [4], and the $\mathrm{pH}$ gradient [5] of the stratum corneum (SC), regulates at least three epidermal functions: antimicrobial barrier, permeability barrier and barrier integrity/cohesion [6]. The relevance of an acid skin surface $\mathrm{pH}$ as an antimicrobial barrier has been demonstrated repeatedly [2,7-10]. At a $\mathrm{pH}$ of 5.0 growth of pathogenic bacteria, like $\mathrm{S}$. aureus, is inhibited in vitro and in vivo. Species of the normal resident flora are positively affected by the physiological, acidic milieu [7-10]. Further, the dissociation of endogenous bacteria from skin surface is enhanced at alkaline conditions [2].
More recent studies provide insight into the skin surface $\mathrm{pH}$ performing a key role in SC functions as permeability barrier homeostasis and SC integrity/cohesion (the converse of desquamation) [6]. Permeability barrier homeostasis depends on the $\mathrm{pH}$ gradient throughout the SC. When acute perturbed skin sites are exposed to a neutral pH buffer [11] or to "superbases" [12], barrier recovery is delayed. These $\mathrm{pH}$-induced barrier abnormalities are associated with an inhibition of two lipid processing enzymes, $\beta$-glucocerebrosidase ( $\beta$-GlcCer'ase) and acid sphingomyelinase (aSMase), which exhibit low $\mathrm{pH}$ optima and transfer polar lipids as, glucosylceramide and sphingomyelin, to the non-polar barrier organization [13-16].

Furthermore, SC integrity/cohesion depends on the activity of $\mathrm{pH}$-dependent serinproteases (SP) of the kallikrein family, such as kallikrein-5 (KLK5, SC tryptic enzyme, SCTE), kallikrein-7 (KLK7, SC chymotryptic en- 
zyme, SCCE) and kallikrein-8 (KLK8, neuropsin) [17]. KLK5 and KLK7 play a key role in integrity/cohesion in desquamation, which exhibit neutral pH optima [18-19]. Desmoglein 1 (DSG1), desmocollin 1 (DSC1) and corneodesmosin (CDSN) are extracellular protein structures of corneodesmosomes. Desquamation is linked to the degradation of DSG1, DSC1 and CDSN by kallikreins [20]. The acidic SC pH regulates KLK5 and KLK7 by reducing, but not completely inhibiting, their activities and by maintaining physiological desquamation. Because of the $\mathrm{pH}$-gradient from 7 (Stratum granulosum (SG)/SC interface) to below 5 (skin surface) the activities of KLK5 and KLK7 change accordingly [6,17].

An increased skin surface $\mathrm{pH}$ has been described repeatedly in the elderly: Zlotogorski et al. [21] showed significant higher skin ph values in the over- 80 group in comparison to the younger groups. Thune et al. [22] demonstrated a higher $\mathrm{pH}(5.7 \pm 0.15)$ in the elderly (67 - 95 years, mean age 81) and revealed a positive correlation between age and $\mathrm{pH}$. These results are in line with those of Wilhelm et al. [23], who found higher values on the ankles of elderly subjects ( $70.5 \pm 13.8$ years). Man et al. [24] retrieved $\mathrm{pH}$ values of approx 6.0 on the forearms and foreheads of male and female subjects in the age group over-70. Moreover, in aged mice an elevated $\mathrm{pH}$ was demonstrated at all levels throughout the SC by Choi et al. [25].

While an elevated $\mathrm{pH}$ inhibits the activity of the lipid-processing enzymes $\beta$-GlcCer'ase and aSMase, which results in inadequate formation of lamellar lipid bilayers, the activity of KLK5 and KLK7 is increased, which results in premature degradation of corneodesmosomes. The functional consequences are 1) delayed barrier recovery [11-12]; 2) reduced barrier integrity/cohesion $[12,26]$ and 3 ) negative effects on the skin microbiota [2]. In the context of aged skin, delayed barrier recovery $[25,27]$ and an impaired barrier integrity $[25$, 27-28] has been demonstrated in the elderly.

The aim of our pilot study was to investigate possible normalization of an increased skin $\mathrm{pH}$ of the elderly and improvement of barrier function by application of skin care products with a pH $3.5-4.0$.

\section{Materials and Methods}

\subsection{Volunteers}

Primarily, the effect of a single application of a given $\mathrm{o} / \mathrm{w}$ emulsion on the skin surface $\mathrm{pH}$ was assessed in ten elderly females (range $81-95$, mean $85.3 \pm 4.8$ ) and ten young females $(31-48,39.1 \pm 6.4)$. A time course of 7 hours after single application of the given $\mathrm{o} / \mathrm{w}$ emulsion was performed on five elderly females $(81-87,82.6 \pm$ $2.5)$ compared to five young females (31 - 49, 38.2 \pm 8.2 ).
Secondly, the effect of a 4-week treatment with a pH 4.0 skin care product on the skin surface $\mathrm{pH}$, skin hydration and barrier integrity was assessed. Thirteen elderly females $(80-90,84.5 \pm 3.9)$ were involved in this homein-use test.

The study was approved by the local ethics committee of the University of Osnabrück (Germany) which gave it unanimous approval. Written, informed consent was obtained from all volunteers. The volunteers were healthy without any skin diseases or lesions on the test sites.

\subsection{Material}

Skin surface $\mathrm{pH}$ was measured with a flat glass electrode (Mettler-Toledo, Giessen, Germany) attached to a $\mathrm{pH}$ meter (Skin-pH-Meter ${ }^{\circledR}$ PH905, Courage \& Khazaka, Cologne, Germany) and SC hydration was determined by a capacitate-based corneometer (Corneometer ${ }^{\circledR}$ CM825, Courage \& Khazaka, Cologne, Germany). Furthermore, barrier function was determined by measuring transepidermal water loss (TEWL). TEWL was measured using an open chamber device (Tewameter ${ }^{\circledR}$ TM300, Courage \& Khazaka, Cologne, Germany). For the evaluation of barrier integrity strippings on the volar forearm were necessary, for which we used a commercially available adhesive tape (3M Blenderm surgical tape, 3M Deutschland, Neuss, Germany).

\subsection{Test Products}

The different $\mathrm{pH}$ values of the tested $\mathrm{o} / \mathrm{w}$ emulsions were adjusted with citric acid $(<0.5 \%)$. The test products were $\mathrm{A}(\mathrm{pH} 3.5), \mathrm{B}(\mathrm{pH} 4.0), \mathrm{C}(\mathrm{pH} 4.5)$ and $\mathrm{D}(\mathrm{pH} 5.5)$. According to INCI ingredients were aqua, arachis hypogaea oil, prunus amygdalus dulcis oil, simmondsia chinensis seed oil, pentylene glycol, cetearyl alcohol, glyceryl stearate, glycerin, oenothera biennis oil, persea gratissima oil, persea gratissima oil unsaponifiables, prunus domestica seed oil, potassium palmitoyl hydrolyzed wheat protein, rosmarinus officinalis leaf extract, panthenol, xanthan gum, citric acid, tocopherol.

\subsection{Experimental Design}

The present study was divided into two sequential parts. The first part (skin surface $p H$ time curves) employed the evaluation of a single application of a given o/w emulsion with different $\mathrm{pH}$ values on the skin surface $\mathrm{pH}$ of the volar forearm of elderly (80+ years old) in comparison to middle aged adults ( 31 - 50 years old). The second part (functional assessment) focused on the evaluation of the long-term effect of a $\mathrm{pH} 4.0 \mathrm{o} / \mathrm{w}$ emulsion on skin $\mathrm{pH}$, skin hydration and barrier integrity after a 4-week treatment. The assessment of the skin pH time curves was carried out in a nursing home in Osnabrück (Germany) at 
room temperature $\left(21.7^{\circ} \mathrm{C} \pm 1.4^{\circ} \mathrm{C}\right.$; relative humidity $46.2 \% \pm 3.8 \%$ ) and the functional assessment at the volunteer home (temperature $20.2^{\circ} \mathrm{C} \pm 2.6^{\circ} \mathrm{C}$; relative humidity $49.4 \% \pm 6.5 \%)$.

\subsection{Skin pH Time Curves}

There was a 12-hour pre-trial period, during which volunteers were requested to refrain from applying any skin care products and tap water to the test sites. The control and treated sites $(50 \times 60 \mathrm{~mm})$ were attributed at random to each volunteer on the midvolar aspect of each forearm with a 4-cm distance to the cubital fossa. To get skin $\mathrm{pH}$ time curves we first measured the basal $\mathrm{pH}$ on the test sites on the volar forearm. We next applied $0.09 \mathrm{~g}(=3$ $\mathrm{mg} / \mathrm{cm}^{2}$ ) of the test products to the respective test site with a plastic syringe (Omnifix ${ }^{\circledR}-\mathrm{F}, \mathrm{B}$. Braun Melsungen AG, Melsungen, Germany). The cream was spread with a gloved finger in a standardized way. For the 2-hour period, the skin surface $\mathrm{pH}$ was measured every twenty minutes after application. For the 7-hour period, the skin surface $\mathrm{pH}$ was measured after twenty minutes and thereafter every 2 hours. The point of measuring of every test area was changed to avoid a wash-out effect from the water drop from the skin $\mathrm{pH}$ meter.

\subsection{Functional Assessment}

To evaluate the functional effects (functional assessment) of an acid cream on aged skin, i.e. aged permeability barrier, a 4-week home-in-use-test was performed. The volunteers were instructed to use the test product $(\mathrm{o} / \mathrm{w}$ cream, $\mathrm{pH}$ 4.0) twice daily on the test sites. In this study the volar aspect of the forearm was used to determine barrier integrity before and after application of the test product. To assess changes in skin surface $\mathrm{pH}$ and skin hydration the forehead (photoaged skin, pa) and the medial upper arm (chronological aged skin, ca) were involved and compared. Before any product treatment the basal skin surface $\mathrm{pH}$ and skin hydration was measured (Basis). On the forearm the barrier integrity, i.e. number of strippings to disturb the barrier, was evaluated according to Gunathilake et al. [29]. TEWL values were measured after every five tape strippings and the strippings were repeated until TEWL increased by three fold. The practical procedure of the stripping itself was performed according to Dickel et al. [30]. Tape strips were gently pressed downward by fingertips for about 2 seconds and tape was removed on one quick movement at an angle of $45^{\circ}$ in the direction of adherence. For each single strip a new tape cut was used and positioned on exactly the same skin area. The basal barrier integrity was assessed on randomized change of left or right forearm. The barrier integrity after the 4-week treatment (day
28) was assessed on both forearms.

\subsection{Statistical Analysis}

Statistical analysis was performed using SPSS software version 18.0 (SPSS, Chicago, IL, USA). Differences between the test sites were tested for their statistical significance using the Mann-Whitney $U$-test for not normally distributed non-paired data. To compare the nonparametric paired values of each test site the Wilcoxon signed-rank test was used. The significance level was set at $p \leq 0.05$. All measured and calculated parameters are reported as arithmetic mean and standard deviation (mean $\pm \mathrm{SD}$ ). The Skin surface $\mathrm{pH}$ of each volunteer was converted to the hydrogen ion concentration. The arithmetic mean of the hydrogen ionic concentration was calculated for the respective group and this in turn converted to a $\mathrm{pH}[31]$.

\section{Results}

\subsection{Skin pH Time Curves}

Baseline skin $\mathrm{pH}$ values, which are significantly $(p<$ 0.006 ) higher in the elderly compared to middle aged adults, are presented in Figure 1. In the context of a 2-hour measurement ten very old females were compared with ten middle aged adults and in the context of the 7-hour measurement five very old were compared with five middle aged females. The baseline skin surface $\mathrm{pH}$ of the volar forearm was $5.50 \pm 0.54$ in the fifteen elderly and $4.98 \pm 0.39$ in the fifteen younger volunteers (Figure 1).

Figure 2(a) reveals skin surface $\mathrm{pH}$ values over the duration of 2 hours after single application of an o/w emulsion with a $\mathrm{pH}$ of 3.5, 4.0, 4.5 and 5.5 on the volar

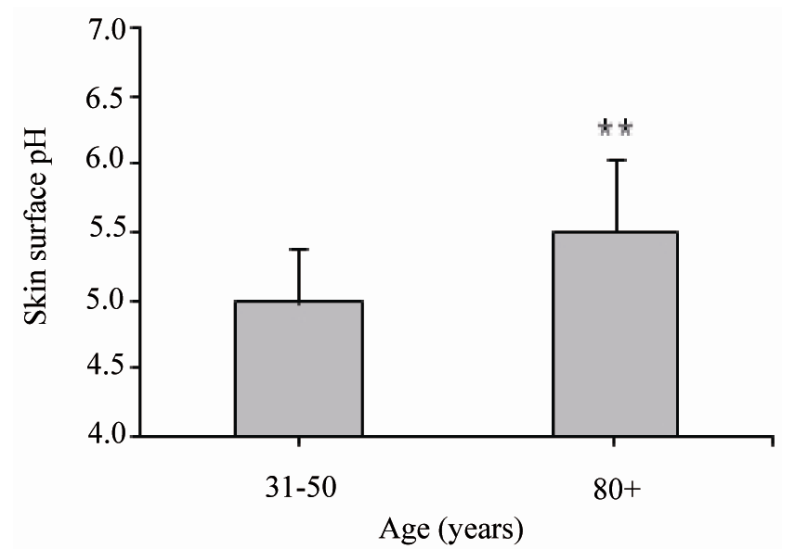

Figure 1. Mean values \pm SD of the skin surface $p H$ of middle aged adults (31 - 50 years old, $n=15)$ and elderly $(80+$ years old, $n=15$ ) on the ventral surface of the lower arm. $* * p \leq 0.01$ : significantly different from middle aged adults. 
forearm in ten middle aged adults.

The skin surface $\mathrm{pH}$ decreased after application of the test product $\mathrm{A}(\mathrm{pH} 3.5)$. The skin surface $\mathrm{pH}$ remained stable around 5 after application of test product $\mathrm{B}(\mathrm{pH} 4.0)$ and $\mathrm{C}(\mathrm{pH} 4.5$ ). Applying a $\mathrm{pH} 5.5 \mathrm{o} / \mathrm{w}$ emulsion (product D) leads to an increase of the skin surface pH up to 5.4. The skin surface $\mathrm{pH}$ of the aged volunteers shows a decrease of 0.8 units after application of the $\mathrm{pH} 3.5$ cream $(5.40>4.58)$ and a decrease of approximately 0.5 units after application of the $\mathrm{pH} 4.0$ cream $(5.33>4.86)$. The application of these creams leads to a skin surface $\mathrm{pH}$ of 4.5 to 5.0 over at least 2 hours. Application of the $\mathrm{pH} 4.5$ and $\mathrm{pH} 5.5$ creams is reflected by a decrease of the skin $\mathrm{pH}$, but not below pH 5.0 (Figure 2(b)).

Next we assessed the influence of two different test products on the skin $\mathrm{pH}$ over a 7-hour period in five elderly (Figure 3) and five middle aged adults.

For this measurement we select the $\mathrm{pH} 3.5$ and $\mathrm{pH} 4.0$ cream, which leads to stabilization of the skin surface $\mathrm{pH}$ between 4.5 and 5.0 (Figure 2(b)). Figure 3 shows a decreased skin $\mathrm{pH} 20$ minutes after application of both test products of 1.0 unit ( $\mathrm{pH} 3.5$ cream) and 0.6 units $(\mathrm{pH} 4.0$ cream). The skin surface $\mathrm{pH}$ of the elderly reveals values between 4.5 and 5.0 over at least 7 hours.

\subsection{Functional Assessment}

We next evaluated the long-term effects after treatment with a $\mathrm{pH} 4.0 \mathrm{o} / \mathrm{w}$ emulsion on permeability barrier function. The focus was on the assessment of the barrier integrity (numbers of stripping required to increase TEWL by three fold) before and after 4-week treatment with the $\mathrm{pH} 4.0$ cream. To disturb the barrier, i.e. increased TEWL by three fold, $10.85 \pm 2.9$ strippings were required. After a 28 day treatment period employing the $\mathrm{pH} 4.0$ test product, we assessed the barrier integrity of both forearms, i.e. of the pre-irritated (A) as well as of a non-irritated control site (B). To increase the TEWL by three fold on the pre-irritated skin, $18.00 \pm 7.62$ strip-

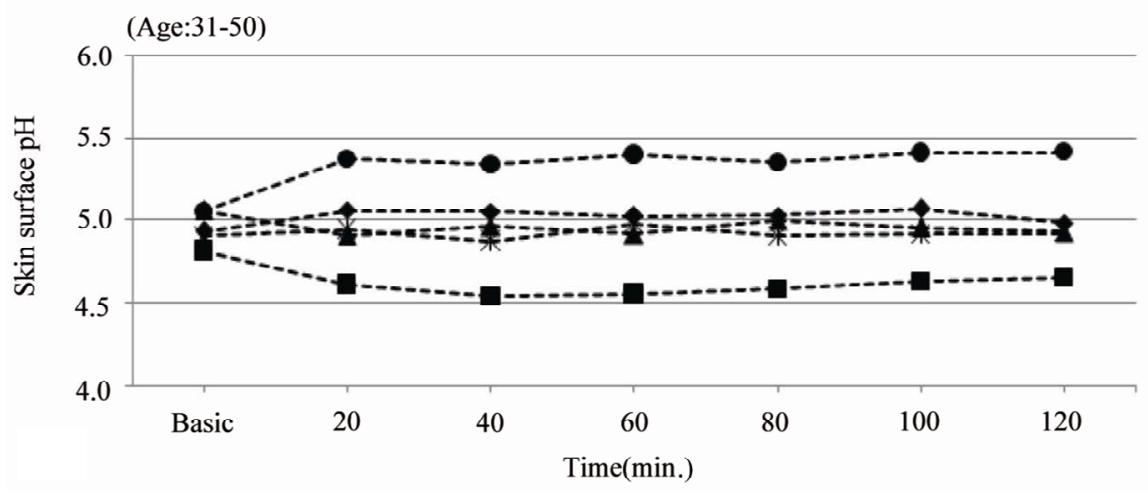

(a)

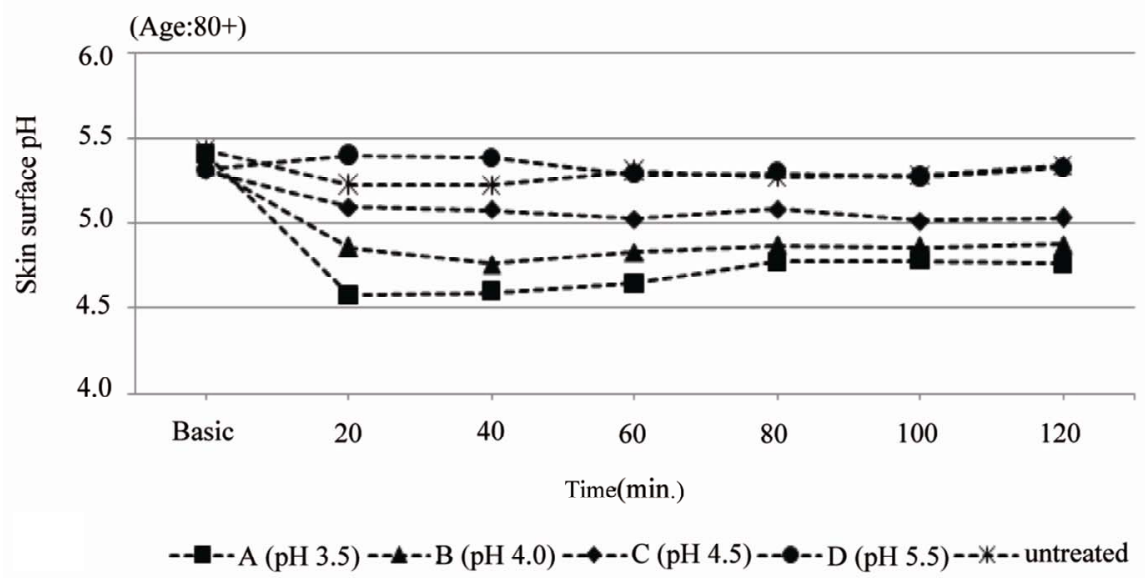

(b)

Figure 2. Skin surface pH (arithmetic mean). (a) gives the skin surface pH over the duration of 120 min after single application of test product $\mathrm{A}(\mathrm{pH} \mathrm{3.5)}, \mathrm{B}(\mathrm{pH} \mathrm{4.0)}, \mathrm{C}(\mathrm{pH} \mathrm{4.5)}$ and $\mathrm{D}$ (pH 5.5) on the volar forearm of middle aged adults (31 - 50 years old, $n=10)$; (b) gives the skin surface $\mathrm{pH}$ over the duration of $120 \mathrm{~min}$. after single application of test product $\mathrm{A}(\mathrm{pH}$ 3.5), B (pH 4.0), C (pH 4.5) and D (pH 5.5) on the volar forearm of elderly (80+ years old, $n=10)$. 


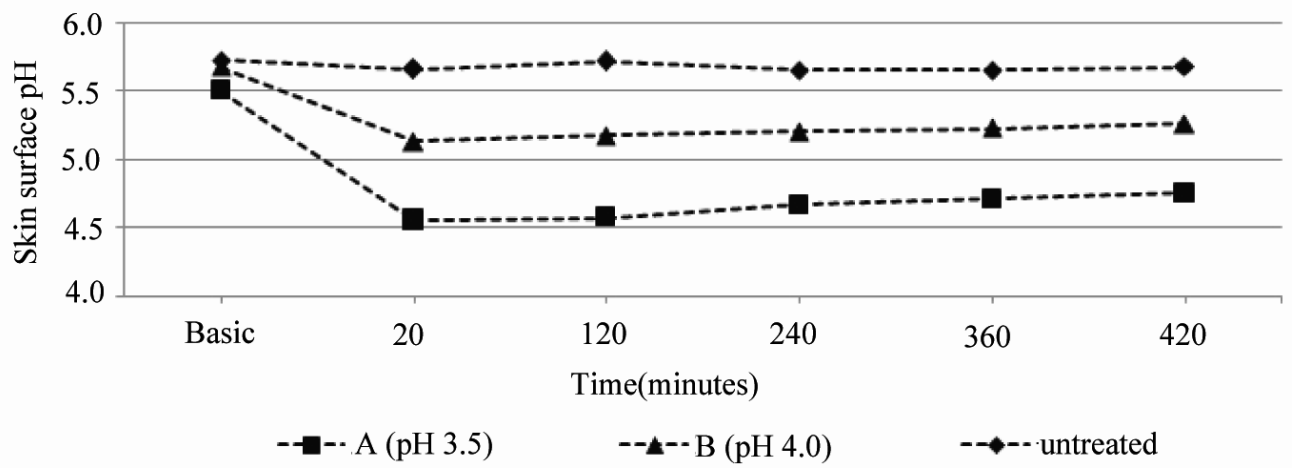

Figure 3. Mean values of the skin surface $\mathrm{pH}$ over the duration of 7 hours after single application of test product $\mathrm{A}$ (pH 3.5) or B (pH 4.0) on the volar forearm of elderly $(80+$ years old, $n=5)$.

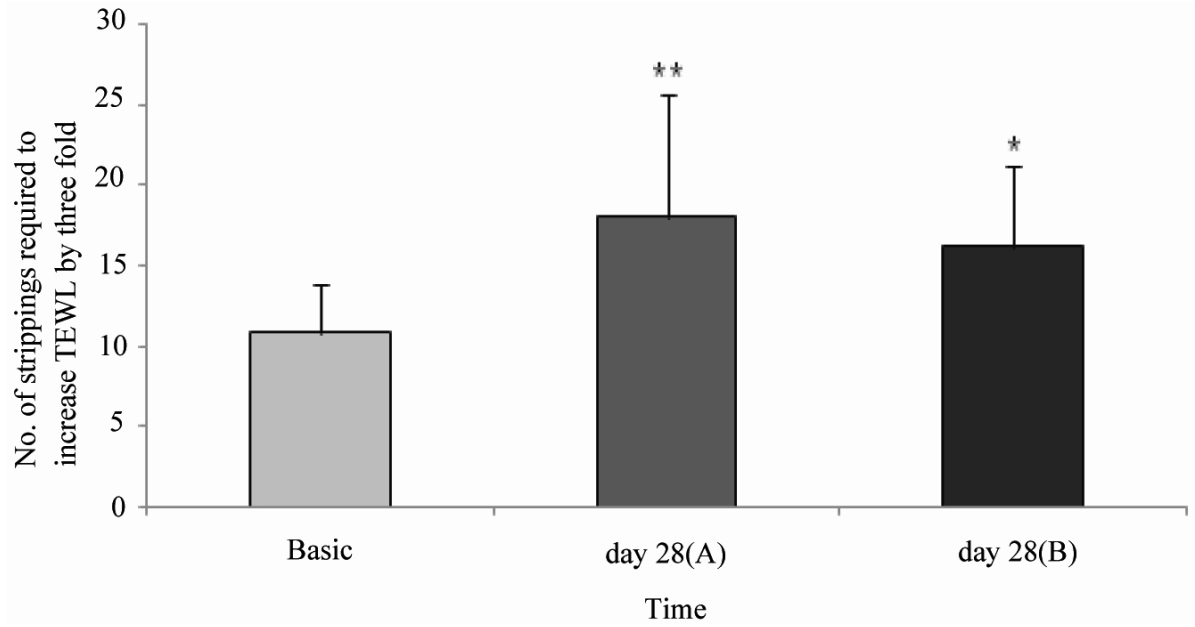

Figure 4. Mean values \pm SD of the numbers of tape strippings required to increase the TEWL by three fold. TEWL measurements were taken prior to tape strippings (Basis) and after a 28 day treatment with a pH4.0 o/w emulsion on the pre-irritated (pre-stripped) location (A) and non-irritated (non-stripped) location (B). ${ }^{*} p \leq 0.05, * * p \leq 0.01$ : significantly different from day 0 (Basis).

pings were employed. $16.15 \pm 5.26$ strippings were required for the non-irritated site. Barrier integrity significantly improved after the 4-week treatment period with the $\mathrm{pH} 4.0$ test product (pre-irritated site: $p \leq 0.01$, and non-irritated site: $p \leq 0.05$ ) (Figure 4). Furthermore, the skin surface $\mathrm{pH}$ and hydration before, during and after the 4-week treatment period was assessed. Skin surface $\mathrm{pH}$ and "skin" hydration were measured on chronological aged (ca, medial upper arm) and photoaged (pa, forehead) skin. The skins surface $\mathrm{pH}$ decreased significantly by 0.3 units on the upper arm $(p \leq 0.01)$ and by 0.6 units on the forehead $(p \leq 0.01)$ after a 7 day treatment period with a $\mathrm{pH} 4.0$ test product (Table 1). Figure 5 shows skin surface $\mathrm{pH}$ and skin hydration values at day 0 (Basis) and after a 4-week treatment period (day 28). On day 28 a significant decrease in skin $\mathrm{pH}$ of approximately 0.4 units on ca $(p \leq 0.01)$ and 0.7 units on pa $(p \leq 0.001)$ was noticed (Figure 5(a)). A significant increase in skin hy- dration was assessed already on day 7,14 and 21 in ca ( $p$ $\leq 0.01)$ and pa $(p \leq 0.05)$. Skin hydration continued to increase up to day 21 on both skin sites (Table 1). On day 28 skin hydration was increased only on the upper arm compared to the baseline value $(p \leq 0.05)$ (Figure 5(b))

\section{Discussion}

An increased skin surface $\mathrm{pH}$ of 5.5 to 6.0 has been previously described in aged skin [21-25]. In agreement with these findings, baseline skin surface $\mathrm{pH}$ values ranged from 5.5 to 6.0 in this study. The observed baseline $\mathrm{pH}$ values were significantly higher $(p \leq 0.01)$ in the elderly $(5.50 \pm 0.54)$ compared to the young $(4.98 \pm 0.39)$ group.

Many experimental in vivo procedures have been developed for assessing the modulation and changing of the skin surface $\mathrm{pH}$ by exogenous influences, like tap water [2,32], alkaline soaps or syndets [32-35] and various 
Table 1. Comparison of chronological aged (ca) with photoaged skin (pa) under 4-week treatment with a pH $4.0 \mathrm{cream}(\mathrm{n}=13)$.

\begin{tabular}{ccccc}
\hline & \multicolumn{2}{c}{ Skin hydration $(\mathrm{AU})$} & \multicolumn{2}{c}{ Skin surface pH } \\
\hline Time & ca & pa & ca & pa \\
Basis & $50.91 \pm 9.12$ & $45.00 \pm 13.34$ & $5.59 \pm 0.58$ & $5.18 \pm 0.59 * *$ \\
Day 7 & $59.12 \pm 6.96^{* *}$ & $54.16 \pm 8.84^{* *}$ & $5.30 \pm 0.49^{* *}$ & $4.88 \pm 0.80^{* *}$ \\
Day 14 & $60.31 \pm 10.51^{* *}$ & $53.12 \pm 9.28^{*}$ & $4.98 \pm 0.76^{* *}$ & $4.96 \pm 0.53^{* * *}$ \\
Day 21 & $58.33 \pm 10.37^{* *}$ & $52.19 \pm 10.56^{*}$ & $5.11 \pm 0.47^{* *}$ & \\
Day 28 & $57.45 \pm 7.91^{*}$ & $49.36 \pm 11.27 \mathrm{~ns}$ & $5.23 \pm 0.42^{* *}$ & $5.06 \pm 0.53^{* * *}$ \\
\hline
\end{tabular}

Values are shown as arithmetic mean \pm standard deviation (SD); ns: no significance, ${ }^{*} p \leq 0.05,{ }^{*} p \leq 0.01$, $* * p \leq 0.001$; Statistical significance was calculated for each time point in comparison to the related baseline with Mann-Whitney-U test; AU: arbitrary unit; ca: chronological aged skin; pa: photoaged skin.

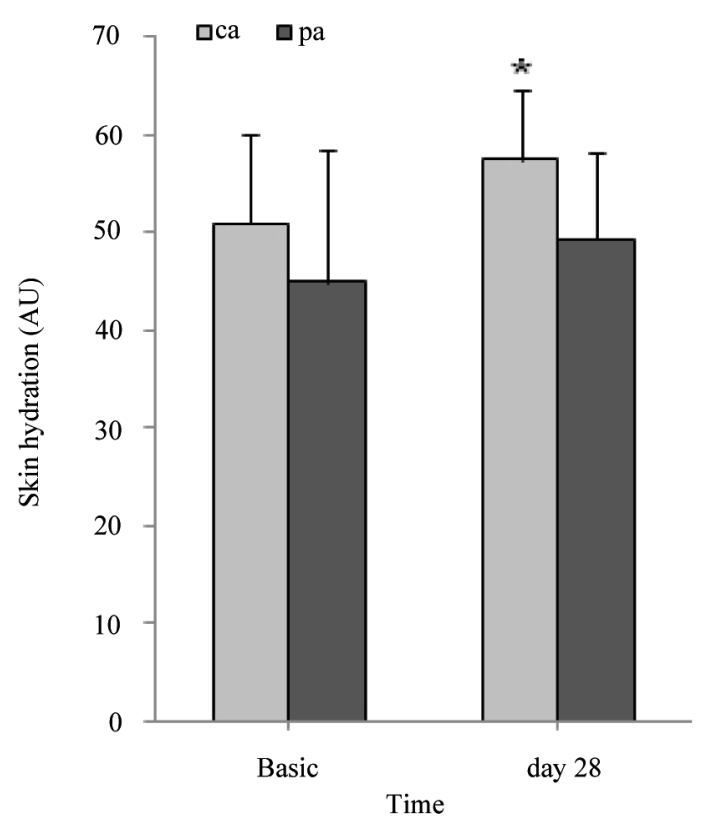

(a)

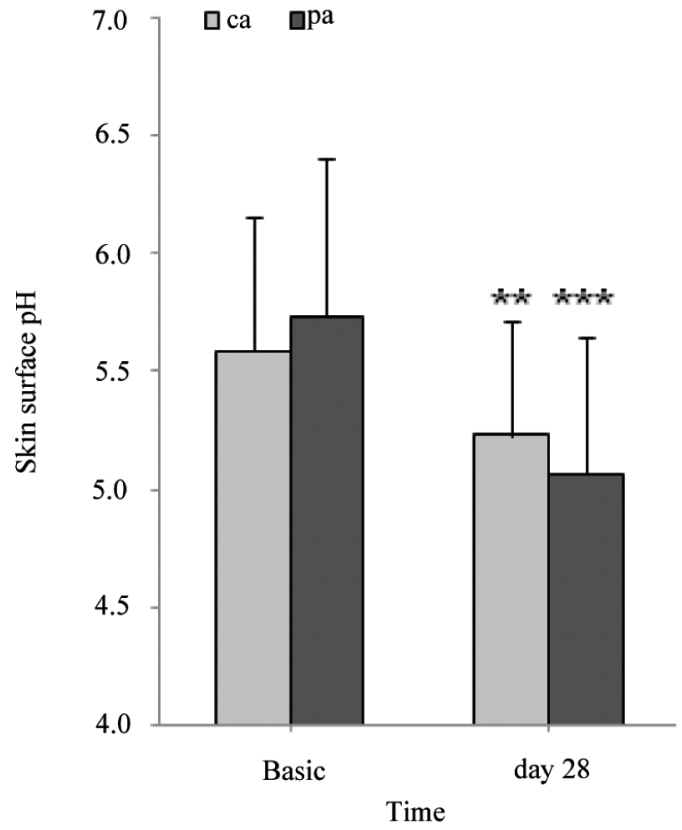

(b)

Figure 5. Skin surface $\mathrm{pH}$ and skin hydration (AU). (a) gives the mean values \pm SD of skin surface pH on the untreated side as well as 28 days thereafter; (b) gives the mean values \pm SD of skin hydration on the untreated side as well as 28 days thereafter. AU: arbitrary unit. ${ }^{*} p \leq 0.05,{ }^{* *} p \leq 0.01,{ }^{* * *} p \leq 0.001$ : significantly different from day 0 (Basis).

topical products [36-38]. Today it is well known, that already a single application with tap water [2] or washing emulsions [39] leads to an increased skin surface $\mathrm{pH}$ up to 6 for up to 8 hours. Moreover, a long-term treatment with rinse-off [33] or leave-on [36] products can decrease the skin surface $\mathrm{pH}$ over weeks.

Taking these findings into account, we first assessed if the increased skin surface $\mathrm{pH}$ of elderly can be normalized by topical application of an acidic o/w emulsion: The skin surface $\mathrm{pH}$ in the elderly (5.5 to 6.0) decreases by single topical application of a $\mathrm{pH} 3.5$ or $\mathrm{pH} 4.0 \mathrm{o} / \mathrm{w}$ cream to the physiological $\mathrm{pH}$ range of 4.5 to 5.0 over a 7 -hour time period.

An important SC function is barrier integrity/cohesion (the converse of desquamation). This SC function is related to the activity of the $\mathrm{pH}$ dependent enzymes KLK5 and KLK7, which exhibit neutral pH optima [18,19]. The extracellular protein structures DSC1, DSG1, and CDSN are part of the corneodesmosomes. Desquamation is linked to the degradation of these protein structures by KLK5 and KLK7. The activity of KLK5 and KLK7 is regulated by the physiological $\mathrm{SC} \mathrm{pH}$ of 4.5 to 5.0 by reducing, but not completely inhibiting their activities. Therefore, controlled desquamation is ensured at physiological SC pH [6,17]. Conversely, an increased SC pH raises the activity of KLK5 and KLK7, which leads to premature degradation of corneodesmosomes, i.e. reduced barrier integrity/cohesion [12,26]. In the context of aged skin impaired barrier integrity is described [25, 27-28].

In consideration of these processes, we next assessed whether the normalization of the increased skin $\mathrm{pH}$ of the elderly leads to enhanced barrier integrity. After the 4week treatment with a $\mathrm{pH} 4.0$ cream (o/w emulsion) bar- 
rier integrity on the volar forearm of thirteen elderly $(80+$ years old) was significantly ( $p \leq 0.05$ and $p \leq 0.01)$ improved in comparison to the baseline barrier integrity. Our findings are in line with Fluhr et al. [40], who showed improved barrier integrity after exogenous acidification in neonatal skin, Choi et al. [25], who described an enhanced barrier integrity after acidification of moderately aged human and rodent skin and Hachem et al. [12] who showed "supernormal" barrier integrity/cohesion after SC acidification in hairless mice. In another context, Gunathilake et al. [29] demonstrated a correlation between low skin surface $\mathrm{pH}$ (between 4.5 and 5.0) and enhanced barrier functions like recovery and integrity/cohesion. Kim et al. [36] observed in young skin (20 - 35 years old) a significantly decreased TEWL after 2-week application of an acidic $(\mathrm{pH} 3)$ skin care product in comparison to the other products $(\mathrm{pH} 8$ and $\mathrm{pH} 5)$. Moreover, a significantly increased TEWL after SLS-irritation on the $\mathrm{pH}$ 8-applied skin site was observed when compared to the $\mathrm{pH} 3$ - and $\mathrm{pH}$ 5-applied skin sites. In contrast, Buraczewska and Lodén [41] found no superiority of a $\mathrm{pH} 4.0$ cream over a $\mathrm{pH} 7.5$ cream. They assessed no significant differences in barrier recovery after treatment with creams of $\mathrm{pH} 4.0$ and 7.5 in volunteers aged 21 to 54 years.

Between $70 \%$ and $85 \%$ [42-45] of the elderly suffer from skin problems (xerosis, pruritus) and skin diseases (contact dermatitis, other eczema, candidiasis). Barland et al. [46] assumed a strong correlation between the abnormal aged barrier function and the abnormal skin conditions in the elderly. Because of this the development of a specific skin care for the very old ( $80+$ years old) is required. This pilot study demonstrates that skin care for the elderly need to be adjusted in the $\mathrm{pH}$ range of 3.5 to 4.0. We postulate that long-term acidic skin care $(\mathrm{pH} 3.5$ to $\mathrm{pH} 4.0$ ) normalizes the increased skin $\mathrm{pH}$ of the elderly, improves the integrity of the epidermal barrier and therefore reduces skin problems in the elderly. Finally in the future it needs to be demonstrated which changes can be achieved under long-term $\mathrm{pH} 4.0$ skin care treatment referring to clinical, patient relevant and physiological respective biochemical skin barrier parameters.

\section{REFERENCES}

[1] O. B. Falco and H. C. Korting, "Der Normale pH-Wert der Menschlichen Haut," Der Hautarzt, Vol. 37, No. 3, 1986, pp. 126-129.

[2] H. Lambers, S. Piessens, A. Bloem, H. Pronk and P. Finkel, "Natural Skin Surface $\mathrm{pH}$ is on Average below 5, which is Beneficial for Its Resident Flora," International Journal of Cosmetic Science, Vol. 28, No. 5, 2006, pp. 359-370. doi:10.1111/j.1467-2494.2006.00344.x

[3] D. Segger, U. Aßmus, M. Brock, J. Erasmy, P. Finkel, A.
Fitzner, H. Heuss, U. Kortemeier, S. Munke, T. Rheinländer, H. Schmidt-Lewerkühne, W. Schneider and G. Weser, "Multicenter Study on Measurement of the Natural $\mathrm{pH}$ of the Skin Surface," IFSCC Magazine, Vol. 10, No. 2, 2007, pp. 107-110.

[4] H. Schade and A. Marchionini, "Der Säuremantel der Haut (Nach Gaskettenmessung)," Klinische Wochenschrift, Vol. 7, No. 1, 1928, pp. 12-14. doi:10.1007/BF01711684

[5] H. Öhman and A. Vahlquist, "In Vivo Studies Concerning a $\mathrm{pH}$ Gradient in Human Stratum Corneum and Upper Epidermis," Acta Dermato-Venereologica, Vol. 74, No. 5, 1994, pp. 375-379.

[6] P. M. Elias, "Stratum Corneum Defensive Functions: An Integrated View," Journal of Investigative Dermatology, Vol. 125, No. 2, 2005, pp. 183-200.

[7] K. T. Holland, W. J. Cunliffe and C. D. Roberts, "The Role of Bacteria in Acne Vulgaris: A New Approach," Clinical and Experimental Dermatology, Vol. 3, No. 3, 1978, pp. 253-257.

[8] H. C. Korting, "Das Säuremantelkonzept von Marchioni und die Beeinflussung der Resident-Flora der Haut durch Waschungen in Abhängigkeit vom pH-Wert," In: O. Braun-Falco and H. C. Korting, Ed., Hautreinigung mit Syndets, Springer Verlag, Berlin, 1990, pp. 93-103.

[9] H. Kurabayashi, K. Tamura, I. Machida and K. Kubota, "Inhibiting Bacteria and Skin $\mathrm{pH}$ in Hemiplegia: Effects of Washing Hands with Acidic Mineral Water," American Journal of Physical Medicine and Rehabilitation, Vol. 81, No. 1, 2002, pp. 40-46. doi:10.1097/00002060-200201000-00007

[10] H. C. Korting, A. Lukacs, N. Vogt, J. Urban, W. Ehret and G. Ruckdeschel, "Influence of the pH-Value on the Growth of Staphylococcus epidermidis, Staphylococcus aureus and Propionibacterium acnes in Continuous Culture," Zentrallblatt für Hygiene und Umweltmedizin, Vol. 193, No. 1, 1992, pp. 78-90.

[11] T. Mauro, W. M. Holleran, S. Grayson, W. N. Gao, M. Q. Man, E. Kriehuber, M. Behne, K. R. Feingold and P. M. Elias, "Barrier Recovery is Impeded at Neutral pH, Independent of Ionic Effects: Implications for Extracellular Lipid Processing," Archives of Dermatological Research, Vol. 290, No. 4, 1998, pp. 215-222. doi:10.1007/s004030050293

[12] J. P. Hachem, D. Cumrine, J. Fluhr, B. E. Brown, K. R. Feingold and P. M. Elias, " $\mathrm{pH}$ Directly Regulates Epidermal Permeability Homeostasis, and Stratum Corneum Integrity/Cohesion," Journal of Investigative Dermatology, Vol. 121, No. 2, 2003, pp. 345-353. doi:10.1046/j.1523-1747.2003.12365.x

[13] W. M. Holleran, Y. Takagi, G. Imokawa, S. Jackson, J. M. Lee and P. M. Elias, "Beta-Glucocerebrosidase Activity in Murine Epidermis: Characterization and Localization in Relation to Differentiation," Journal of Lipid Research, Vol. 33, No. 8, 1992, pp. 1201-1209.

[14] J. M. Jensen, S. Schutze, M. Forl, M. Kronke and E. Proksch, "Roles for Tumor Necrosis Factor Receptor p55 and Sphingomyelinase in Repairing the Cutaneous Per- 
meability Barrier," Journal of Clinical Investigation, Vol. 104, No. 12, 1999, pp. 1761-1770. doi:10.1172/JCI5307

[15] M. Schmuth, M. Q. Man, F. Weber, W. Gao, K. R. Feingold, P. Fritsch, P. M. Elias and W. M. Holleran, "Permeability Barrier Disorder in Niemann-Pick Disease: Sphingomyelin-Ceramide Processing Required for Normal Barrier Homeostasis," Journal of Investigative Dermatology, Vol. 115, No. 3, 2000, pp. 459-466. doi:10.1046/j.1523-1747.2000.00081.x

[16] Y. Takagi, E. Kriehuber, G. Imokawa, P. M. Elias and W. M. Holleran, "Beta-Glucocerebrosidase Activity in Mammalian Stratum Corneum," Journal of Lipid Research, Vol. 40, No. 5, 1999, pp. 861-869.

[17] P. Ovaere, S. Lippens, P. Vandenabeele and W. Declercq, "The Emerging Roles of Serine Protease Cascades in the Epidermis," Trends in Biochemical Science, Vol. 34, No. 9, 2009, pp. 453-463. doi:10.1016/j.tibs.2009.08.001

[18] M. Brattsand and T. Egelrud, "Purification, Molecular Cloning, and Expression of a Human Stratum Corneum Trypsin-Like Serine Protease with Possible Function in Desquamation," The Journal of Biological Chemistry, Vol. 274, No. 42, 1999, pp. 30033-30040. doi:10.1074/jbc.274.42.30033

[19] E. Ekholm and T. Egelrud, "Expression of Stratum Corneum Chymotryptic Enzyme in Relation to Other Markers of Epidermal Differentiation in a Skin Explant Model," Experimental Dermatology, Vol. 9, No. 1, 2000, pp. 65-70. doi:10.1034/j.1600-0625.2000.009001065.x

[20] C. Caubet, N. Jonca, M. Brattsand, M. Guerrin, D. Bernard, R. Schmidt, T. Egelrud, M. Simon and G. Serre, "Degradation of Corneodesmosome Proteins by Two Serine Proteases of the Kallikrein Family, SCTE/KLK5/ hK5 and SCCE/KLK7/hK7," Journal of Investigative Dermatology, Vol. 122, No. 5, 2004, pp. 1235-1244. doi:10.1111/j.0022-202X.2004.22512.X

[21] A. Zlotogorski, "Distribution of Skin Surface $\mathrm{pH}$ on the Forehead and Cheek of Adults," Archives of Dermatological Research, Vol. 279, No. 6, 1987, pp. 398-401. doi:10.1007/BF00412626

[22] P. Thune, T. Nilsen, I. K. Hanstad, T. Gustavsen and H. Lovig Dahl, "The Water Barrier Function of the Skin in Relation to the Water Content of Stratum Corneum, $\mathrm{pH}$ and Skin Lipids. The Effect of Alkaline Soap and Syndet on Dry Skin in Elderly, Non-Atopic Patients," Acta Dermato-Venereologica, Vol. 68, No. 4, 1988, pp. 277-283.

[23] K. P. Wilhelm, A. B. Cua and H. I. Maibach, "Skin Aging. Effect on Transepidermal Water Loss, Stratum Corneum Hydration, Skin Surface pH, and Casual Sebum Content," Archives of Dermatology, Vol. 127, No. 12, 1991, pp. 1806-1809.

[24] M. Q. Man, S. J. Xin, S. P. Song, S. Y. Cho, X. J. Zhang, C. X. Tu, K. R. Feingold and P. M. Elias, "Variation of Skin Surface $\mathrm{pH}$, Sebum Content and Stratum Corneum Hydration with Age and Gender in a Large Chinese Population," Skin Pharmacology and Physiology, Vol. 22, No. 4, 2009, pp. 190-199. doi:10.1159/000231524
[25] E. H. Choi, M. Q. Man, P. Xu, S. Xin, Z. Liu, D. A. Crumrine, Y. J. Jiang, J. W. Fluhr, K. R. Feingold, P. M. Elias and T. M. Mauro, "Stratum Corneum Acidification Is Impaired in Moderately Aged Human and Murine Skin," Journal of Investigative Dermatology, Vol. 127, No. 12, 2007, pp. 2847-2856. doi:10.1038/sj.jid.5700913

[26] J. W. Fluhr, J. Kao, M. Jain, S. K. Ahn, K. R. Feingold, and P. M. Elias, "Generation of Free Fatty Acids from Phospholipids Regulates Stratum Corneum Acidification and Integrity," Journal of Investigative Dermatology, Vol. 117, No. 1, 2001, pp. 44-51. doi:10.1046/j.0022-202x.2001.01399.x

[27] R. Ghadially, B. E. Brown, S. M. Sequeira-Martin, K. R. Feingold and P. M. Elias, "The Aged Epidermal Permeability Barrier. Structural, Functional, and Lipid Biochemical Abnormalities in Humans and a Senescent Murine Model," Journal of Clinical Investigation, Vol. 95, No. 5, 1995, pp. 2281-2290. doi:10.1172/JCI117919

[28] J. Blaak, D. Lüttje, S. M. John and N. Y. Schürer, "Irritability of the Skin Barrier: A Comparison of Chronologically Aged and Photoaged Skin in Elderly and Young Adults," European Geriatric Medicine, Vol. 2, No. 4, 2011, pp. 208-211. doi:10.1016/j.eurger.2011.05.011

[29] R. Gunathilake, N. Y. Schurer, B. A. Shoo, A. Celli, J. P. Hachem, D. Crumrine, G. Sirimanna, K. R. Feingold, T. M. Mauro and P. M. Elias, "pH-Regulated Mechanisms Account for Pigment-Type Differences in Epidermal Barrier Function," Journal of Investigative Dermatology, Vol. 129, No. 7, 2009, pp. 1719-1729. doi:10.1038/jid.2008.442

[30] H. Dickel, T. M. Bruckner, S. M. Erdmann, J. W. Fluhr, P. J. Frosch, J. Grabbe, H. Loffler, H. F. Merk, C. Pirker, H. J. Schwanitz, E. Weisshaar and J. Brasch, "The 'Strip' Patch Test: Results of a Multicentre Study towards a Standardization," Archives of Dermatological Research, Vol. 296, No. 5, 2004, pp. 212-219. doi:10.1007/s00403-004-0496-X

[31] M. Kober, "Bestimmung des Hautoberflächen-pH bei Probanden: Methodik und Ergebnisse im Rahmen Klinischer Studien," In: O. Braun-Falco and H. C. Korting, Ed., Hautreinigung mit Syndets, Springer Verlag, Berlin, 1990, pp. 57-66.

[32] R. Gfatter, P. Hackl and F. Braun, "Effects of Soap and Detergents on Skin Surface pH, Stratum Corneum Hydration and Fat Content in Infants," Dermatology, Vol. 195, No. 3, 1997, pp. 258-262.

[33] A. O. Barel, R. Lambrecht, P. Clarys, B. M. Morrison Jr. and M. Paye, "A Comparative Study of the Effects on the Skin of a Classical Bar Soap and a Syndet Cleansing Bar in Normal Use Conditions and in the Soap Chamber Test," Skin Research and Technology, Vol. 7, No. 2, 2001, pp. 98-104. doi:10.1034/j.1600-0846.2001.70208.x

[34] H. M. Gunathilake, G. M. Sirimanna, and N. Y. Schurer, "The pH of Commercially Available Rinse-off Products in Sri Lanka and Their Effect on Skin pH," Ceylon Medical Journal, Vol. 52, No. 4, 2007, pp. 125-129.

[35] H. C. Korting, K. Hubner, K. Greiner, G. Hamm and O. 
Braun-Falco, "Differences in the Skin Surface $\mathrm{pH}$ and Bacterial Microflora Due to the Long-Term Application of Synthetic Detergent Preparations of $\mathrm{pH} 5.5$ and $\mathrm{pH}$ 7.0. Results of a Crossover Trial in Healthy Volunteers," Acta Dermato-Venereologica, Vol. 70, No. 5, 1990, pp. 429431.

[36] E. Kim, S. Kim, G. W. Nam, H. Lee, S. Moon and I. Chang, "The Alkaline pH-Adapted Skin Barrier Is Disrupted Severely by SLS-Induced Irritation," International Journal of Cosmetic Science, Vol. 31, No. 4, 2009, pp. 263-269. doi:10.1111/j.1468-2494.2009.00491.x

[37] S. Stenzaly-Achtert, A. Schölermann, J. Schreiber, K. H. Diec, R. Rippke and S. Bielefeldt, "Axillary pH and Influence of Deodorants," Skin Research and Technology, Vol. 6, No. 2, 2000, pp. 87-91. doi:10.1034/j.1600-0846.2000.006002087.x

[38] R. R. Wickett and C. M. Trobaugh, "Personal Care Products," Cosmetics \& Toiletries, Vol. 105, No. 7, 1990, pp. 41-46.

[39] A. Post, M. Gloor and W. Gehring, "Über den Einfluss der Hautwaschung auf den Haut-pH-Wert," Dermatologische Monatsschrift, Vol. 178, No. 5, 1992, pp. 216-222.

[40] J. W. Fluhr, M. Mao-Qiang, B. E. Brown, J. P. Hachem, D. G. Moskowitz, M. Demerijan, M. Haftek, G. Serre, D. Crumrine, T. M. Mauro, P. M. Elias and K. R. Feingold, "Functional Consequences of a Neutral $\mathrm{pH}$ in Neonatal
Rat Stratum Corneum," Journal of Investigative Dermatology, Vol. 123, No. 1, 2004, pp. 140-151. doi:10.1111/j.0022-202X.2004.22726.X

[41] I. Buraczewska and M. Lodén, "Treatment of Surfactant-Damaged Skin in Humans with Creams of Different pH Values," Pharmacology, Vol. 73, No. 1, 2005, pp. 1-7.

[42] S. Beauregard and B. A. Gilchrest, "A Survey of Skin Problems and Skin Care Regimens in the Elderly," Archives of Dermatology, Vol. 123, No. 12, 1987, pp. 16381643. doi:10.1001/archderm.123.12.1638

[43] S. Ward, "Eczema and Dry Skin in Older People: Identification and Management," British Journal of Community Nursing, Vol. 10, No. 10, 2005, pp. 453-456.

[44] K. Weismann, R. Krakauer and B. Wanscher, "Prevalence of Skin Diseases in Old Age," Acta Dermato-Venereologica, Vol. 60, No. 4, 1980, pp. 352-353.

[45] R. A. Norman, "Geriatric Dermatology," Dermatologic Therapy, Vol. 16, No. 3, 2003, pp. 260-268. doi:10.1046/j.1529-8019.2003.01636.x

[46] C. O. Barland, P. M. Elias and R. Ghadially, "The Aged Epidermal Permeability Barrier: Basis for Functional Abnormalities," In: P. M. Elias and K. R. Feingold, Ed., Skin Barrier, Taylor \& Francis, New York, 2005, pp. 535-552. 